\title{
Phengite in carbonate rock syngenetically formed from hydrothermal fluid: micro-textural evidence and mineral chemistry
}

\author{
ChAEWON PARK ${ }^{1}$, NAMSOO KIM $^{1}$, YunGOO SONG $^{1 *}$ \\ ${ }^{1}$ Yonsei Univ. BK21+ institute of Earth. Atmosphere. \\ Astronomy, Seoul, Korea \\ (*correspondence: yungoo@yonsei.ac.kr)
}

Phengite, the muscovite-celadonite solid solution, occurred as not only a lath form of single crystal but also a large aggregates with micro-sized grains in the Haengmae Formation, which is newly defined as dolomite-pebble bearing fine sand-sized dolostone of Cambro-Ordovician Joseon Supergroup in South Korea. Based on micro-textural observation, phengite is mainly observed as a form surrounding the detrital grains and a precipitate filling pore spaces, which is followed by the precipitation of calcite. This occurrence strongly suggests that the phengite formed syngenetically or during early diagenesis by the infiltration of hydrothermal fluid in carbonaceous sedimentary rocks (Haengmae Fm.) that are hosted within mixed sequences of dominantly fine- to medium-grained clastic carbonate rocks. The structural formula based on $\mathrm{O}_{10}(\mathrm{OH})_{2}$ shows that the number of $\mathrm{Mg}$ per formula unit (p.f.u.) ranges from 0.1 to 0.6 (average $=0.5$ ), which is relatively high, compared with metamorphic phengite. In terms of micro-textural evidence and mineral chemistry, the appearance of syngenetic phengite in the Haengmae Fm. is expected to be used as key data in solving geological problems related to the debate on the existence of Silurian Hoedongri Fm. in South Korea. 